\title{
Punishing War Crimes, Genocide, and Crimes against Humanity: Introduction
}

\author{
Jesper Ryberg
}

Published online: 4 February 2010

(C) Springer Science+Business Media B.V. 2010

The establishment of the International Criminal Court (the ICC) as the first permanent legal institution designed to deal with 'the most serious crimes of concern to the international community ${ }^{1}$ has in recent years attracted increasing attention among moral philosophers. This is not surprising. The sad fact that war crimes, genocides, and crimes against humanity-constituting the subject-matter jurisdiction of the ICC - are parts of the existing world (dis)order, naturally prompts the question as to how one should handle such crimes once they have occurred. More narrowly, the punitive questions addressing themselves in relation to the ICC are: Is an international punishment institution morally justified? Who should be held accountable? And how should perpetrators be punished for their misdeeds? The purpose of this volume is to contribute to a discussion of these questions.

The opening article concerns the "how much" question. The overwhelming gravity of the most atrocious mass crimes obviously causes one to wonder what would constitute the proper punitive response to such crimes. Or, as Michael Davis puts the question: Does the ICC's jurisdiction consist primarily of crimes too big for criminal justice? Drawing on his fairness-theoretic version of retributivism and a theory of enforcement, Davis seeks to answer this question. In contrast, the ensuing two articles engage in different ways in considerations of who should be held accountable for mass crimes. Operating within the framework of an expressive theory of punishment, Bill Wringe addresses the question as to whether those who are punished for war crimes and those who punish belong to the same community; he also considers the implications with regard to what constitutes a legitimate distribution of punishment. Larry May, for his part, directs attention to the concept of complicity. Taking his point of departure from the fact that one-third of the

\footnotetext{
1 The Rome Statute, Article 5.
}

J. Ryberg ( $ه)$

Department of Philosophy, The University of Roskilde, P6, Post Box 260, 4000 Roskilde, Denmark e-mail: ryberg@ruc.dk 
population of Rwanda-over one million people-was estimated to be in some sense complicit in the genocide that occurred in 1994, he investigates the border between legal and moral complicity.

An obvious question to which the ICC has given rise, is whether the punishment of mass crimes raises genuinely new challenges relative to those usually addressed in penal theoretical reflections on the punishment of ordinary crimes dealt with by domestic courts. That international criminal justice does in fact prompt new problems is accentuated in the contributions by both Claudie Tamburrini and Jesper Ryberg. Tamburrini presents what he calls an 'internal critique' of hard-core retributivism and advances a negotiation model that offers gross human rights abusers substantial punishment reductions in exchange for valuable information in the aftermath of mass crimes. Ryberg's purpose is to direct attention to a challenge - referred to as the 'threshold challenge' — which he argues constitutes a both theoretically and practically pertinent problem for a non-absolutist retributivist approach to the punishment of mass crimes.

The consequences of punishing mass atrocities are brought into focus in several of the contributions. On the ground of the assumption that the central purpose of punishment is the prevention of crime, Anthony Ellis seeks to establish where the burden of proof lies between those who do, and those who do not, favour the trial and punishment of war criminals by international institutions. Michael Clark and Peter Cave, in their article, consider the rationale of the law of war and proceed to reflect on the justification of punishing war crimes arguing for a consequentialist view with certain side-constraints. The traditional consequentialist emphasis of deterrence is also addressed in the article by Jakob Holtermann, who discusses a particular model for combining the ICC and the use of truth and reconciliation commissions.

In contrast to the foregoing articles, the main purpose of the final contribution is not to consider problems of penal theory, but to apply such considerations to international criminal justice. More precisely, Angelo Corlett examines the actions taken by the US in Iraq in the light of just war principles, and sets forth a programme for holding accountable those people most responsible for the war crimes which he holds have been committed in Iraq. The article thereby serves as a reminder of the simple fact that, however interesting the theoretical challenges of international criminal justice may be, they arise from a ground of tragic realities. 